УДК $811.111+81^{\prime} 42$

DOI https://doi.org/10.26661/2414-1135-2021-82-17

\title{
МОВНІ ЗАСОБИ РЕАЛІЗАЦІЇ ТАКТИК МАНІПУЛЯТИВНОГО ВПЛИВУ В СУЧАСНИХ АНГЛОМОВНИХ МАС-МЕДІА
}

\author{
Коваленко А. М. \\ кандидат філологічних наук, доиент, \\ дочент кафедри германської філології \\ Сумський державний педагогічний університет імені А. С. Макаренка \\ вул. Роменська, 87, Суми, Украӥна \\ orcid.org/0000-0001-6439-5089 \\ andriy.kov.09@gmail.com \\ Новікова В. С. \\ магістрант факультету іноземної та слов'янської філології \\ Сумський державний педагогічний університет імені А. С. Макаренка \\ вул. Роменська, 87, Суми, Україна \\ orcid.org/0000-0003-2932-9312 \\ nevilval@gmail.com
}

Ключові слова: мас-медіа, фейкові новини, комунікативні тактики, маніпулятивний вплив, стилістичні засоби.
Стаття присвячена аналізу мовних засобів реалізації тактик маніпулятивного впливу в сучасних англомовних мас-медіа. Відповідно, досліджуються основні тактики впливу, які дезінформують читача, дезорієнтують в інформаційному шумі, схарактеризований їх вплив на громадськість через використання ефективних стилістичних засобів. Таким чином, вивчаються мовні засоби, що реалізують тактики фейкових новин і закладають у свідомості читачів визначені сценарії розвитку громадської думки.

Тактики впливу на суспільну свідомість вирізняються цілями та намірами автора медіатексту і спрямовані на кооперативну взаємодію з читачем завдяки правильному добору мовних засобів. Вони добре вписуються в політику постправди, яка розмиває межі об'єктивних фактів й оцінних суджень.

Автор визначає наслідки інформаційного впливу на суспільну свідомість, виокремлюючи комунікативні тактики мас-медіа: абсурдизації, гіперболізації, посилання на авторитет, впливу на емоції та почуття, відкритої критики, надання неточної інформації, самовиправдання, газлайтингу, обіцянки, погрози, викриття, алогізму, поради тощо. Вони визначають таку подачу інформації в медіатексті, зреалізовану через лексичні й стилістичні мовні маркери, яка залежить від ракурсу висвітлення певних подій.

Аналіз впливу мас-медіа на суспільну свідомість дає змогу стверджувати, що від вибору тактик залежить рівень активізації емоційної сфери людини, їі чуттєвого сприйняття інформації. Перспективою дослідження розглядається визначення тактик як психологічних прийомів у певних фрагментах тексту, що спонукають читачів робити ірраціональні висновки. 


\title{
THE LANGUAGE MEANS OF MANIPULATIVE IMPACT TACTICS REALIZATION
} IN MODERN ENGLISH MASS MEDIA

\author{
Kovalenko A. M. \\ Candidate of Philological Sciences, Associate Professor, \\ Associate Professor at the Chair of Germanic Philology \\ Sumy State Pedagogical University named after A. S. Makarenko \\ Romenska str., 87, Sumy, Ukraine \\ orcid.org/0000-0001-6439-5089 \\ andriy.kov.09@gmail.com \\ Novikova V. S. \\ Master's Degree Student at the Department of Foreign and Slavic Philology \\ Sumy State Pedagogical University named after A. S. Makarenko \\ Romenska str., 87, Sumy, Ukraine \\ orcid.org/0000-0003-2932-9312 \\ nevilval@gmail.com
}

Key words: mass-media, fake news, communicative tactics, manipulative influence, stylistic devices.

\begin{abstract}
The article focuses on the analysis of language means to realize tactics of manipulative impact in modern English mass media.

In this regard we explore the main tactics of influence that make readers feel confused in the information flow through effective stylistic devices use. This modern method of psychological influence retains strong power over various spheres of life, including politics, medicine etc. and makes the networked Fourth Estate primary one. Thus, the research studies language means which realize the tactics of fake news in the mind of readers that create certain effect on public opinion.

The influence tactics on the public consciousness are distinguished by the goals and intentions of media text author and are aimed at cooperative interaction with the reader through the correct language means selection. They fit well into a posttruth policy that blurs the line between objective facts and evaluative judgments. The research investigates the consequences of informational impact on public consciousness, highlighting the communicative tactics of the media such as absurdization, hyperbole, reference to authority, influence on emotions and feelings, open criticism, inaccurate information, self-justification, gaslighting, promises, threats, exposure, alogism, advice etc. They determine the presentation of information in the media text implemented through lexical and stylistic language means, that depend on perspective of certain events coverage.

The public consciousness media-impact analysis made it possible to claim that emotional state and information perception level of a person depends on selection of special manipulative tactics. The research perspective is to define various tactics as psychological techniques in certain text paterns, that encourage readers to make irrational conclusions.
\end{abstract}

Постановка проблеми. 3 розвитком популярності соцмереж мас-медіа почали активну боротьбу за сенсацію. В умовах розмитих меж між об'єктивною інформацією та несправжніми фактами вони стали співучасниками в поширенні хибних відомостей задля комерційної вигоди та залучення більшої аудиторії. Підроблені новини почали заміняти традиційні журналістські тексти, адже подавали неоднозначну інтерпретацію інформації, щоб привернути увагу до повідомлення, спонукати до певної дії. Їх ретранслятори стали стрімко просувати фейкові матеріали, використовуючи ефективні засоби впливу на суспільну свідомість. 
Аналіз останніх досліджень та публікацій. Тактики маніпулятивного впливу на свідомість користувачів мас-медіа $є$ потужними інструментами для формування громадської думки, ілюзії діалогу з читачем. Це питання стало предметом досліджень щодо медійного дискурсу, зокрема фейкових новин $[10 ; 5 ; 8]$. Найповніше це розкрито через комунікативні тактики, виражені дієвими мовними засобами 3 вигідними відтінками значень, що спонукає лінгвістів глибше вивчати механізми їх впливу $[1 ; 2 ; 3 ; 4 ; 6 ; 7 ; 9]$. Саме тому, зважаючи на мовленнєві маніпуляції, необхідно з'ясувати стилістичні маркери фейків в англомовних мас-медіа, що мають виразний ефект на свідомість особистості.

Метою роботи $є$ аналіз мовних засобів реалізації тактик маніпулятивного впливу та їх вияв у фейкових новинах. Досягнення поставленої мети потребує вирішення таких завдань:

- дослідити визначення комінікативних тактик у сучасному англомовному мас-медійному дискурсі;

- виокремити тактики маніпулятивного впливу ретрансляторів фейкових новин;

- проаналізувати мовні засоби, через які зреалізовані психологічні прийоми впливу на громадськість.

Об'єктом дослідження $є$ маніпулятивні тактики фейкових новин в англомовному медіадискурсі, предметом - мовні засоби реалізації цих тактик. Емпіричну базу дослідження становлять медіатексти в сучасних англомовних 3МI.

Виклад основного матеріалу. Поняття комунікативних стратегій і тактик не має однозначних і чітких визначень, оскільки існують різні підходи до їх тлумачень. У лінгвістичній літературі вони розуміються як деяка послідовність мовленневих дій, організованих залежно від мети взаємодії; оптимальна реалізація інтенцій мовця щодо досягнення конкретної мети спілкування, тобто контроль і вибір дієвих ходів спілкування та гнучкої їх видозміни в конкретній ситуації [1, с. 133].

Т. ван Дейк та В. Кінч класифікують їх за характером розуміння дискурсу на пропозиційні, схематичні, продукційні, стилістичні, риторичні, невербальні, конверсаційні, стратегії локальної зв'язності та макростратегії [2]. О. Іссерс вказує, що стратегії реалізуються через комунікативні тактики, інструментами яких $є$ комунікативні ходи методи і прийоми, які окремо або в комплексі ведуть до вирішення надзадачі. Специфікою мовленнєвих стратегій взагалі і мовленнєвих тактик зокрема $\epsilon$ комплексність застосування мовних засобів для досягнення комунікативної мети [3, с. 83].

Л. Павлова аналізує комунікативні цілі англомовних медіа, що належать до політичного дискурсу, встановлює мовну специфіку медіатек- стів, підпорядковану стратегіям інформування, самопрезентації та консолідації [6]. Натомість дослідниця В. Посмітна виявляє їх в аспекті загроз мас-медійного впливу, що можуть становити небезпеку в разі використання з метою інформаційної агресії. На іiі думку, від загальних можливостей мас-медіа та вибору комунікативних стратегій залежить рівень гігієни інфосфери чи поширення певних ідей [7].

Стратегії впливу містять комунікативні ходи та тактики, приховані у фейкових матеріалах, що несуть потужне змістове навантаження. Вони мають різні лінгвістичні інтерпретації і втілені в тексті за допомогою лексичних, граматичних та стилістичних засобів, що значно увиразнює передачу інформації. Суб'єктивна модальність знаходить своє вираження не тільки у виборі емотивних лексичних засобів, але і в широкому спектрі стилістичних засобів виразності [5, с. 153]. Саме тому за допомогою мовного багатства та певної лінгвокультурної специфіки виникає емоційна реакція в читача. Цим пояснена висока продуктивність їх застосування в текстах.

Мовленнєва стратегія визначає семантичний (когнітивний), стилістичний та прагматичний вибір. За рахунок вибору маємо змогу говорити про гнучкість стратегії, яка забезпечується динамічністю тактик. Тактика сама по собі невербальна, вона складається з конкретних так званих мовленнєвих «ходів» або прийомів. У текстах ЗМІ вони побудовані залежно від вибору очікуваного прагматичного ефекту, способу інформаційної трансформації, форми іiї пред'явлення, маніпулятивної потенції мовних засобів або відповідно до моделі об'єкта маніпуляції - свідомості людини [8, с. 267-268]. Існує велика кількість прийомів, пов'язаних зі значеннями мовних виразів, які застосовують для того, щоб подати певну інформацію про реальні події у вигідному світлі відповідно до інтересів певної людини, соціальної або політичної групи [9, с. 121-122]. Тому проілюструємо реалізацію лінгвальних засобів через тактики маніпулятивного впливу прикладами.

Тактику гіперболізачїі використовують автори новин як один 3 інструментів створення комічного. Так, опис побутових тривіальних речей (наприклад, старих продуктів у холодильнику) може переростати в засторогу глобальної катастрофи, яка поглине людство: «Coupled with seven or eight different sorts of milk and yoghurt and you've basically got ground zero for the annihilation of the human race in three to six weeks》. Засiб zіперболи поєднується із порівнянням: «I can't stress this enough: your fridge is now worse than one of those Chinese markets where they sell bats and Anteaters and one of Vladimir Putin's top-secret labs put together» (News Thump - October 21, 
2020). Актуальність новини тут підкреслена тим, що йдеться про значущі та нагальні проблеми, а саме появу коронавірусу в Китаї та загрозу з боку потенційного супротивника.

Гіпербола часто поєднана 3 іншими засобами увиразнення мовлення, наприклад, 3 антитезою: "You think we're a bunch of people who look like Kraftwerk, sitting in a clock-covered spaceship that is calibrated to the last nano-second. Actually it's a rented room above Greenwich Wetherspoons and we drink heavily through boredom» (News ThumpOctober 21, 2020). У разі нелогічного або суперечливого представлення фактів гіперболізація повідомлюваного посилює комічний ефект: «The cat, 4-year-old Simon Purrliams, told his owner he has lost almost half his body weight since hoovering up half a pack of whiskas at $\mathbf{9}$ pm yesterday - leaving him at severe risk of malnutrition and even death» (The Daily Mash - October 23, 2020).

Тактика абсурдизаиії пов'язана 3 наведенням несумісних із реальністю фактів або тверджень: «Sub-molecular machines which can journey into the bloodstream and dismantle coronavirus into its component atoms, as well as create diamonds from dust and food from the dirt» (Theonion - January 15, 2018). Навіть 3 урахуванням наукового поступу майбутнього, винайдення подібної машини було б цілком абсурдним. Іншим різновидом абсурдизації $є$ опис подій, що не можуть відбуватися з урахуванням наявних соціальних, культурних та юридичних реалій: "The United Nations announced Wednesday that every single person in the Middle East will receive his or her own sovereign nation as part of a historic 317,000,000-state solution» (The Onion - July 17, 2014). Тим не менш у фейковій новині про офісний холодильник і пандемію коронавірусу використані не пов'язані міжс собою судження, недостовірні факти, в яких закладено вагоме експресивне i змістове навантаження. Так, це підтверджують емоційні вислови у вигляді іменників «pandemic», «humanity», «flamethrower», «fridge» i прикметників «devastate», "fateful», «worse», "sensible», «unnatural» iз негативним значенням, які виявляють оцінне ставлення автора підробленої новини. Такі слова підкріплені експресивними відтінками, щоб читач повірив у повідомлюване: «Scientists have warned against 'clearing out the fridge' when people return to the office, unless it is done in a hazmat suit and preferably with a flamethrower» (News Thump - October 21, 2020). Також у фейковій новині представлені оцінні судження автора новини про властивості коронавірусу та продуктів, збережених у холодильнику, які переплітаються з іронією та абсурдом: «Coupled with seven or eight different sorts of milk and yoghurt and you've basically got ground zero for the annihilation of the human race in three to six weeks» (News Thump - October 21,
2020). Нагромаджсенн у тексті фраз та слів-асоціатів не лише акумулюють психічні процеси, які викликають сильні емоції, а й формують в уяві читачів картинку, яка підводить до деструктивної, апокаліптичної теми: «а pandemic that will sweep the earth and devastate humanity», "on that fateful day when everyone was told not to come into the office», "scientists have warned against 'clearing out the fridge' when people return to the office» (News Thump - October 21, 2020). Поряд із тим у новині наведені власні назви на позначення авторитетності, доказовості, зокрема «Sir Simon Williams», «Vladimir Putin's», «Royal School of Tropical Medicine», що діють як психологічні тригери i нав'язують необхідні установки. Це доповнює порівняння, звернене до універсальних понять, що свідомо заплутує читача, нагнітає страхи: «I can't stress this enough: your fridge is now worse than one of those Chinese markets where they sell bats and Anteaters in spicy sauce and one of Vladimir Putin's top-secret labs put together» (News Thump - October $21,2020) .3$ огляду на це модальність втілена в тексті через висловлення ставлення до подій, що виявляють стереотипні міркування, апеляцію до суб'єктивних думок, алогічних тверджень.

Тактику відкритої критики найчастіше застосовують у політичних фейкових новинах. Важливо, що нерідко іiі центрують навколо кандидатів на виборах. Так, Д. Трамп часто виступає об'єктом відкритої критики, наведемо кілька прикладів: «an openly authoritarian bigot who was indifferent to human life», "imbecilic squint-eyed pumpkin», "selfish terrible human», «rich bloated pig man». Стилістичним маркером такої техніки $€$ пейоративна оцінність та використання зниженої згрубілої лексики, наприклад: «Dastardly was described as a petty and spiteful demagogue who uses overly florid language and is happy to use people to achieve his aims»; "Dastardly, described as a double-dealing do-badder, is on record as being willing to nab, jab, stab and grab to achieve his objectives»; "Well-known scoundrel and bad egg Dick Dastardly» (News Thump - October 30, 2020). Тим не менш маніпулятивний вплив здійснюють за допомогою мовних засобів, які в поєднанні 3 позалінгвальними, певними прийомами організації тексту, структурування та подання інформації застосовують у суспільно-політичних процесах за посередництвом 3МI [4].

Посилання на авторитет є іншою тактикою підвищення довіри читача. Як правило, комічний ефект у такій тактиці втілений завдяки називанню дій, недостойних цього престижу або почесного звання, наприклад: "How Biden can beat Trump: remind progressives that no one's more qualified to dismantle the racist 1994 Crime Bill than its own author» (News Thump - October 
29, 2020). У наступному прикладі комічний ефект досягнутий неможливістю отримання Нобелівської премії за коментар у Фейсбуці: «Today, the Nobel Committee awarded the Nobel Prize for Medicine to all the infectious disease experts who have continuously and selflessly advanced medical research by sharing their knowledge through informed comments and posts on Facebook» (News Thump - October 5, 2020).

Тактика алогізму передбачає не просто ствердження хибної думки, а також опис ії розгортання задля псевдодоказовості. Формальними лексичними маркерами такої техніки є вставні слова типу thus, therefore, that is тощо: «Another bizarre and puzzling quality is its [the virus's] ability to sense the time of day. Schools and offices remain open yet non-workers on the streets at night pose an infection risk, therefore indicating that the virus goes to sleep during the day» (The Onion October 29, 2020). Засобом вираження комізму у фейковій новині $\boldsymbol{\epsilon}$ персоніфікація та антропоморфізація віруса (надання йому людських рис).

Стилістичним засобом вираження тактики викриття є застосування сатири. Особливо показовими $\epsilon$ в цьому плані описи умов роботи, які забезпечують несумлінні роботодавці: «On the surface, it seemed plausible-owning our employees' bodies, implementing a mandatory 18-hour workday, restricting their movements, and not compensating them with anything besides minimal food and shelter - but then it started to sound really familiar in a bad way,» said Bezos» (The Onion - March $28,2018)$. Уведення в новини казкових персонажів посилює стилістичний ефект використання сатири: "We're paid in nothing but candy, have no union representation and are only allowed one toilet break every five hours» (News Thump - December $12,2020)$. Описуючи умови роботи ельфів, автор вводить імпліцитний паралелізм з описом експлуатації працівників роботодавцем.

Газлайтинг - психологічна тактика непрямої конфронтації опонента, в якій співрозмовник натякає на некомпетентність адресата або його нездатність адекватно оцінювати події чи факти. Яскравим прикладом $є$ фейкова новина про нового співробітника NASA, колеги якого заперечували існування місяця. Іронія виступає частиною комунікативної тактики газлайтингу. Типовим для цієї техніки $€$ також посилання на авторитет адресанта, використання будь-яких тверджень, що заставляють адресата сумніватися у власній адекватності: «Look, buddy, I started working here before you were born, and I think I'd know if there was a moon up there. Better slow down and try not to make too many discoveries on your first day, okay? Are you sure you passed the drug test? Because it seems like you're hallucinating moons up there» (The Onion - August 19, 2020).
Тактика прогнозування передбачає застосування граматичних маркерів (умовного способу та майбутнього часу), а також відповідних числівників, що вказують на певну дату в майбутньому. Засоби можуть відрізнятися залежно від специфіки передбачення, чи то позитивної, чи то негативної: «Urging drastic action to mitigate the effects of the imminent herpetological disaster, scientists at the University of Miami warned Friday that Florida could be completely submerged by snakes as early as 2021» (The Onion - October 16, 2020). Маркерами мовної гри часто виступають новотвори, що нагадують вже існуючі слова: «Poppy-geddon due to begin imminently» (News Thump - October 26, 2020). Власне неологізм «poppy-geddon» був отриманий шляхом телескопії (злиття основ). Ненормативна й дерогативна лексика вжита авторами задля підвищення рівня емотивності фейкових новин, внесення елементу розмовності 3 метою бути ближче до читача: "Grandma amazed by how fuckable grandson has gotten since she saw him last»; "Brain-eating microbe in US water supply explains a f*cking hell of a lot, insist scientists» (News Thump - September 27, 2020). У деяких випадках ненормативні та згрубілі слова використовуються учасниками спілкування для вираження свого незадоволення, а також критики: «Donald Trump has been readmitted to hospital. This time, he is suffering from the rare condition of having dangerous quantities of smoke up his arsehole»; "Whatever happens, I have had enough being First Lady. Gold toilet can go to hell»; "'How can they expect me to focus today?' asks man putting in usual half-assed effort at work»; "Dipshits who insisted on going around coughing on their neighbours and not washing their hands have ruined things for everyone else, it has emerged» (The Daily Mash - October 23, 2020).

Тактика протиставлення заснована на різних виражальних засобах, головним чином, антитезі: "Michelle Obama, a woman who once had it all but now is a mere footnote in history» (Daily Squib August 7, 2020). Часто засобом вираження виступає нисхідна градація: «President Xi's announcement was greeted by a noise which at first was believed to be applause, but turned out to be truncheons hitting the heads of Hong Kong democracy campaigners» (News Thump - September 23, 2020). Лексичними маркерами тактики протиставлення виступають абсолютні чи контекстуальні антоніми: «Sеe, I clean up nice, ' announces ugly, dirty man in suit» (Daily Squib - August 7, 2020).

Надання неточної інформачії у фейкових новинах пов'язано з реалізацією засобів творення комічного: «The UK has been reminded that the clocks go forward or possibly back, this Saturday or maybe the Saturday after. The biannual ritual, 
which corrects time for the benefit of the ever-grateful farming community, will give everyone an extra hour in bed, or possibly an hour less» (The Daily Mash October 23, 2020). При цьому встановлення недостовірності або неправдивості вказаної інформації не вимагає від читача додаткових зусиль: «It is expected that England will shortly descend into its annual bout of Poppy insanity, » said Simon Williams, a Professor of ridiculous national hysteria» (News Thump - October 26, 2020).

Тактику поради часто передають засобами іроніï, яка виявлена у формі надання «поради навпаки»: «In order to make sure you maintain a sense of derangement and hostility, we recommend keeping yourself agitated by blasting election coverage at full volume on multiple devices while continuously shrieking batshit insane accusations at imaginary deep-state actors who are trying to destroy America» (The Onion - March 11, 2020). Якщо іiі дають політику або публічній особі, вона може виступати засобом вираження непрямої критики: "Those days are all gone, and Michael misses it all. I suggest that Michelle starts taking drugs to counteract the depression, cocaine and maybe a little meth would pick her spirits up just fine» (Daily Squib - August 7, 2020).

Засобами реалізації тактики погрози с сатира й сарказм. Як правило, вони вжиті у змалюванні найбільш гострих суспільних проблем. Граматичними маркерами тактики погрози можуть виступати дієслівні форми наказового та умовного способу, проте вони можуть бути відсутні: «Until our staffing goals are met, one white person, preferably a straight man, will be publicly executed every 60 minutes, leaving a vacant position for a candidate who represents an historically disadvantaged group» (The Onion - March 14, 2018).

Реалізація тактики обіиянки свідомо покладена на подання хибної інформації щодо майбутніх дій автора та натяк щодо реальних мотивів героя новини: «Listen, my children, and I will tell уоu when the NYSE closing bell rings out and the Dow Jones Industrial Average soars above 27,000 points, I will return to strike down the wicked and reign over the righteous forevermore» (The Onion - January 11, 2018). У цьому випадку комічний ефект реалізується завдяки несумісності архетипного образу Ісуса та приписуваних йому фінансових мотивів.

Тактику самовиправдання реалізують завдяки засобам створення комічного. У центрі осміяння, як правило, знаходяться лінощі працівників: «I honestly don't understand how I'm supposed to [file a report that was due three weeks ago and answer a day-old email from a supervisor] as if nothing else is happening in the world》) (The Onion - September 30, 2020). Низька культура праці підкреслена за допомогою парентези (подання певної інформа- ції в структурі вставних та вставлених конструкцій). Причини своєї поведінки чоловік пояснює за допомогою обставинних причини, допусту та інших типів підрядних: «Williams went on to explain that his new home-based routine had become ever more sedentary, despite the best efforts of people like Joe Wicks. He told us, «But I don't want you to think I'm not looking after my health, I do get up every single hour for a quick walk. Normally it's to the cupboard to get a biscuit» (The Onion September 30, 2020).

Тактика впливу на емоиії $i$ почуття може бути виражена за допомогою низки мовних засобів. Найчастіше до них входять сарказм, сатира, емфаза, парцеляція, обрив, риторичне окличне речення тощо. Об'єктом впливу на емоції можуть виступати історичні та політичні події, наприклад: «Look, we don't want these hungry kids to get fed, and that includes sweets. We don't care about them and we certainly don't want to encourage anyone else to be feeding them either, as that just makes us look even worse than we already do»; "All of the USSR's corruption, hunger, and disease would have disappeared overnight if Stalin had simply been able to let a few million more Ukrainians starve to death» (News Thump - October 26, 2020). У цих прикладах у гострій сатиричній формі автор засуджує жорстокість та нелюдяність політичних лідерів. У рідкісних випадках тактика впливу на емоції показана за допомогою більш легкого гумору, наприклад: «So cold...so hungry... Purrliams told us, pathetically, before turning side on so you would be able to see his ribs if they weren't buried beneath a thick layer of blubber) (The Daily Mash - October 23, 2020). Виражальними засобами, спрямованими на емоційну сферу людини, у цьому уривку $\boldsymbol{\epsilon}$ aнафора (соинопочаток) та обрив. Наділення кота людською мовою $\epsilon$ елементом фантастичної казки i слугує для підживлення інтересу читача. 3 перших слів він привертає увагу описом бідної, нещасної тварини, образ якої увиразнений експресивними відтінками мовних засобів, що показово характеризують репліки кота, зокрема фрази «perhaps you'd better bring the bowl to me here, before...I die», " the brink of starvation", "severe risk of malnutrition and even death» (The Daily Mash - October 23, 2020). За допомогою словесних перебільшень показана маніпуляція фактами, щоб пробудити в читача емоційну сферу. Саме тому в іронічному тоні подана розповідь кота про його страждання, про що красномовно свідчать експресивно наснажені стилістичні засоби на зразок «eight hours of shut-eye», «on the brink of starvation». До того ж підсилювальну функцію виконують словосполучення із займенником I, а саме «I'm not sure...», «I die», що наочно показують причетність героя новини до повідомлюваного. 
Висновки. Таким чином, маніпулятивні тактики фейкових новин мають чималий вплив на масову свідомість та залежать від цілей та ходів автора медіатексту. Такі психологічні прийоми виступають основними способами для реалізації прагматичних функцій і налаштовують на відповідну реакцію читачів. Вони організовані залежно від взаємодії адресата та адрепсанта та втілені в тексті з допомогою різних мовних засобів. За способом, метою комунікації вони можуть мати різний вплив на користувачів мас-медіа, що залежить від ситуативного контексту. Тактики абсурдизації, гіперболізації, газлайтингу, впливу на емоції i почуття, викриття, погрози, обіцянки, самовиправдання, поради визначають форму подачі інформації в медіатексті. Вона зреалізована через стилістичні мовні засоби, які ефективно впливають на емоційну сферу людини. Це підвищує привабливість тексту, сприяє тому, що свідомість читачів має тільки один вектор сприйняття, заданий автором фейку. Такий підхід до подачі матеріалу дає змогу досягти бажаного ефекту, вводити в оману з допомогою підміни понять та маніпуляції. Саме тому у вивченні зазначених питань вбачаємо перспективи подальших досліджень.

\section{ЛITЕРАТУ РА}

1. Дацюк С.А. Коммуникативные стратегии. URL: http://xyz.org.ua/discussion/ communicative strategy.html.

2. Дейк ван Т.А., Кинч В. Стратегии понимания связного текста. Новое в зарубежной лингвистике. 1988. Вып. 23. С. 153-211.

3. Иссерс О.С. Коммуникативные стратегии и тактики русского языка. Москва : Эдиториал УPCC, 2002. $426 \mathrm{c}$.

4. Козак С. Комунікативні стратегії як засіб маніпулятивного впливу в англомовних прес-релізах. Наукові записки Національного університету "Острозька академія». Серія : Філологічна. 2012. № 23. С. 68-70.

5. Омельчук Ю. Псевдоновини як жанр сучасного англомовного медіадискурсу: лінгвокогнітивний, комунікативно-прагматичний параметри : дис. ... канд. філол. наук : 10.02.04/ Запоріз. нац. ун-т. Запоріжжя, 2018. 240 с.

6. Павлова Л.В. Комунікативні стратегії і тактики в англомовному політичному медіадискурсі. Вчені записки Таврійського начіонального університету ім. В.І. Вернадського. Сер.: Філологія. Сочіальні комунікачії. 2018. Т. 29 (68), № 3. C. 55-60.

7. Посмітна В.В. Комунікативні стратегії та тактики мас-медійного дискурсу в аспекті потенційної загрози деструктивного мовного впливу. Науковий вісник Міжнародного гуманітарного університету. Сер.: Філологія. 2019. T. 3, № 39. С. 123-126.

8. Сіденко Н.Г. Інструменти мовленнєвої маніпуляції в англомовній «жовтій» пресі. Записки з романо-германської філології. 2014. № 2. C. $105-113$.
9. Чік Л. Засоби мовного маніпулювання у сучасних ЗМІ. Літературний прочес: методологія, імена, тенденції. Філологічні науки. 2015. № 5. C. 121-123.

10. Morgan S. Fake news, disinformation, manipulation and online tactics to undermine democracy. URL: https://www.tandfonline.com/ doi/full/10.1080/23738871.2018.1462395.

\section{REFERENCES}

1. Dacyuk, S.A. Communication strategies [Kommunikativnye strategii]. URL: http://xyz.org.ua/ discussion/communicative_strategy.html.

2. Dejk, van T.A., Kinch, V. (1988) Strategies for understanding coherent text [Strategii ponimaniya svyaznogo teksta]. Novoe v zarubezhnoj lingvistike. M.: Progress, 1988. Vol. 23. pp. 153-211.

3. Issers, O.S. (2002) Communicative strategies and tactics of the Russian language [Kommunikativnye strategii i taktiki russkogo yazyka]. Moskva : Editorial URSS. 426 p.

4. Kozak, S. (2012) Communicative strategies as means of manipulative impact in English press releases [Komunikativni strategiï yak zasib manipulyativnogo vplivu $\mathrm{v}$ anglomovnih pres-relizah]. Naukovi zapiski Nacional'nogo universitetu «Ostroz'ka akademiya». Seriya : Filologichna. № 23. pp. 68-70.

5. Omel'chuk, Y. (2018) Pseudonews as genre of modern English media discourse: linguistic cognitive, communicative-pragmatic parameters [Psevdonovini yak zhanr suchasnogo anglomovnogo mediadiskursu: lingvokognitivnij, komunikativno-pragmatichnij parametri]: dis. ... kand. filol. nauk : 10.02.04 / Zaporiz. nac. un-t. Zaporizhzhya. $240 \mathrm{p}$.

6. Pavlova, L.V. (2018) Communicative strategies and tactics in the English political media discourse [Komunikativni strategiï $\mathrm{i}$ taktiki v anglomovnomu politichnomu mediadiskursi]. Vcheni zapiski Tavrijs'kogo nacional'nogo universitetu im. V.I. Vernads'kogo. Ser.: Filologiya. Social'ni komunikaciï. Vol. 29 (68), № 3. pp. 55-60.

7. Posmitna, V.V. (2019) Communicative strategies and tactics of mass media discourse in the aspect of potential threat of destructive language influence [Komunikativni strategiï ta taktiki mas-medijnogo diskursu $\mathrm{v}$ aspekti potencijnoï zagrozi destruktivnogo movnogo vplivu]. Naukovij visnik Mizhnarodnogo gumanitarnogo universitetu. Ser.: Filologiya. Vol. 3, № 39. pp. 123-126.

8. Sidenko, N. G. (2014) Speech manipulation tools in the English-language «yellow» press [Instrumenti movlennєvoï manipulyaciï $\mathrm{v}$ anglomovnij «zhovtij» presi]. Zapiski z romano-germans'koï filologiï. № 2. pp. 105-113.

9. Chik, L. (2015) Means of language manipulation in modern media [Zasobi movnogo manipulyuvannya u suchasnih ZMI]. Literaturnij proces: metodologiya, imena, tendenciï. Filologichni nauki. № 5. pp. 121-123.

10. Morgan, S. Fake news, disinformation, manipulation and online tactics to undermine democracy. URL: https://www.tandfonline.com/doi/full/10.1 080/23738871.2018.1462395. 